\title{
Effect of pharmaceutical care intervention on blood pressure of elderly outpatients with hypertension
}

\author{
Divaldo Pereira de Lyra Júnior ${ }^{1,2 *}$, Paulo Sergio Marcellini', Irene Rosemir Pelá2

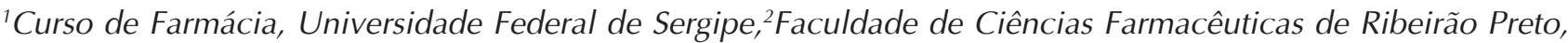 \\ Universidade de São Paulo
}

*Correspondence:

D. P. de Lyra Júnior

Laboratório de Ensino e Pesquisa em

Farmácia Social - LEPFS/ UFS

Curso de Farmácia

Departamento de Fisiologia

Universidade Federal de Sergipe

Av. Marechal Rondon, s.n.- Jardim

Rosa Elze

49000-000 - São Cristóvão - SE, Brasil

E-mail: lyra_jr@hotmail.com,

lepfs.ufs@gmail.com
The purpose of this study was to evaluate the effect of pharmacist intervention on the prevention and solution of drug therapyproblems (DTP), Body Mass Index (BMI), and blood pressure control in elderly outpatients with hypertension. The instruments were applied to 30 elderly outpatients assisted at the pharmacy of a primary health care unit in Ribeirão Preto (SP), Brazil. The group of patients received follow-up during a period of 12 months. It was observed that Pharmaceutical Care intervention optimized the medication use; reduced symptoms caused by drug therapy and improved the elderly patients' health conditions. The Pharmaceutical Care intervention influenced the care given to elderly people as well as the achievement of positive health outcomes. After this study, the researcher gave training about practice of Pharmaceutical Care to 38 dispensing pharmacists from the Public Health-System of Ribeirão Preto. Nowadays, these pharmacists are perpetuating the practice introduced in the region.
Uniterms

- Hypertension

- Elderly

- Pharmaceutical Care

\section{INTRODUCTION}

Hypertension is a common chronic health condition among older people and is the most important risk factor for all subtypes of vascular disease and death. According WHO (2003), the hypertension afflicts approximately 600 million people around the world, including the majority of elderly, and imposes enormous burdens through associated cardiovascular diseases. In Brazil, cardiovascular diseases remain the leading cause of death reaching $32 \%$ of all causes of mortality (Muxfeldt et al., 2004).

Although the benefits of antihypertensive medications are clearly established, only $60 \%$ of hypertensive patients are currently treated, and only $34 \%$ are adequately controlled (Goodley et al., 2003). Moreover, the high incidence of drug-therapy problems (DTP) in elderly patients with hypertension has been reported in literature (Rollason, Vogt, 2003; Garção, Cabrita, 2002).

The economic impact of DTP is enormous in USA, totaling US \$104 billions annually and rivaling the cost of diseases common in the older population (Erwin, 1999). These preventable negative patient outcomes and their associated costs have caught the attention of patients, healthcare professionals, and governmental agencies (Kohn et al., 1999)

In Brazil, most elderly patients with hypertension are using prescribed drugs by the Public Health Care System (SUS) to control the disease. Despite such therapy, most of 
patients have inadequate blood pressure (BP) control, with increased risk of associated cardiovascular morbidity and mortality (Zaitune et al., 2006; Muxfeldt et al., 2004). This uncontrolled hypertension is commonly associated with non-adherence to drug therapy and/or lack of access to health care (Chobanian, 2001). Therefore, changes in SUS are necessary to improve the care of these patients.

In recent years, the shift of health care toward an ambulatory has increased the demand for quality outpatient clinical pharmacy services. Pharmacists have been encouraged to provide Pharmaceutical Care to identify, prevent, and resolve DTP and mediate dialogue with patients and physicians, monitoring and alerting them to uncontrolled BP values and optimizing the pharmacotherapy (Lyra Jr. et al., 2007; Lyra Jr. et al., 2006). Pharmaceutical care has been defined as the responsible provision of drug therapy for the purpose of achieving defined outcomes that improve a patient's quality of life (Hepler, Strand, 1990).

In other countries, previous research have shown that pharmacist involvement in the ambulatorial care of hypertensive patients improves BP control (Lee et al., 2006; Zillich et al., 2005; Vivian, 2002; Mehos et al., 2000). Although, primary care units are the entrance of SUS, it almost does not have studies published about Pharmaceutical Care practice in Brazil (Lyra Jr. et al., 2007; Souza et al., 2007; Castro et al., 2006; Lyra Jr. et al., 2005; Oliveira et al., 2005). Thus, the purpose of this study was to evaluate the effect of pharmacist intervention on the prevention and solution of drug therapy-problems (DTP), Body Mass Index (BMI), and blood pressure control in elderly outpatients with hypertension.

\section{METHODS}

A longitudinal, prospective study (semi-experimental) was conducted at a primary health care unit (PHCU) in Ribeirão Preto (SP), Brazil, from August, 2003 to July, 2004. This setting was chosen because 300 of the patients had hypertension, and the center's health care providers identified $40 \%$ (120) non-adherence as a primary reason for poor outcomes to treatment. At PHCU, the outpatients were attended to by four physicians, two dispensing pharmacists, and one research pharmacist

\section{Patients}

During a week period, all hypertensive outpatients who came to the ambulatory care pharmacy of PHCU to receive their medication were identified as potential candidates for the study. Patients were eligible to participate if they met three or more of the following criteria (Koecheler et al., 1989): five or more drugs in their regimen, twelve or more doses per day, a medication regimen that had changed four or more times in the past year, three or more co-morbidities, a history of medication non-compliance, and the presence of at least one drug that requires therapeutic monitoring (Box 1).

BOX 1 - Drugs requiring therapeutic monitoring

Drug Category
$\beta$-Blockers
Calcium channel blockers
Thiazide diuretics
Angiotensin-converting enzyme inhibitors
Angiotensin II receptor antagonists
$\alpha$-Antagonists
Vasodilators
Biguanides
Sulfonamides
Cholesterol and triglyceride reducers

Exclusion criteria were: stage 3 hypertension (systolic e $\bullet 180 \mathrm{~mm} \mathrm{Hg}$ and/or diastolic pressure e $\bullet 110 \mathrm{~mm}$ $\mathrm{Hg}$ based on JNC-VI criteria), an identified secondary cause of hypertension, such as chronic renal disease, pheochromocytoma, Cushing's syndrome, or had missed more than three appointments during the program.

The nature of the study was described to the patients, and informed consent forms were signed by those eligible and interested in participating.

\section{Pharmaceutical Care program}

Patients were scheduled to visit the research pharmacist once per month at PHCU during the period of a year. The research pharmacist (DPLJ) interviewed each patient for forty minutes, using a checklist with essential issues such as socio-demographic variables, health situation, and drug therapy (Currie et al., 2003). The Pharmaceutical Care interview program included: active listening, review of health situation and drug history, identification of needs and problems, assessment, care plan, documentation, and intervention.

\section{Pharmaceutical Care intervention}

During the Pharmaceutical Care program, interventions aimed at personal transformation and the awakening of patients' "critical consciousness", and were 
divided into: health education and drug therapy (Freire, 1983). Such transformation is attributed to three key consciousness-raising experiences: relating to and reflecting on experience; personal exploration and problem solving; and taking thoughtful action. These steps provide a framework for Freire's participatory social orientation approach to the design of effective educational strategies in health. While originally applied to the teaching of basic literacy skills to adults in Brazil, it has been used internationally in health education (Roter et al., 2001; Freire, 1983).

Educative intervention consisted of: counseling concerning chronic health conditions (nature, causes, and treatment) and changes in lifestyle, identification of signs and symptoms caused by medication (effectiveness and safety), and encouragement of patients to participate actively in the proposed drug therapy.

The research pharmacist evaluated patients individually to identify actual and potential DTP. DTP is any undesirable event experienced by a patient which involves, or is suspected to involve, drug therapy and that interferes with achieving the desired goals of therapy (Cipolle et al., 2004). It was divided in terms of need, effectiveness, and safety (Comité del Consenso, 2002). All data was recorded on an individual form and updated monthly, thus forming a database. The drug therapy intervention also consisted of: assessment of drug history (current and past medication) and drug-taking ability, solution and prevention of DTP (actual and potential), clarification questions regarding orders, use, and storage of medicines and implementation of adherence-improving strategies.

\section{Statistical analysis}

The paired $t$ test was used to measure differences in mean of DTP, Body Mass Index (BMI) and systolic and diastolic BP between baseline and end of this study. All analyses used SPSS (version 12, SPSS Inc., Chicago, IL). A significance level of 0.05 was adopted for all statistical tests. All results were validated by means of Wilcoxon's Rank-sum test.

\section{RESULTS AND DISCUSSION}

\section{Socio-demographic and health situation profile}

The mean age of patients was $66 \pm 5$ years, 20 of whom were women $(n=30)$. Twenty one $(71 \%)$ of the patients had low literacy. In Brazil, individuals with reduced education levels are approximately 5 times as likely to have health problems (Rosa et al., 2003). One of most dramatic problems identified is the extremely poor level of patient knowledge and understanding (Naves, Silver, 2005). In this situation, the educational interventions could contribute to awareness development and to the exchange of experiences, replacing dominant and informative actions that were distant from the patients' reality (Roter et al., 2001). Empowering experiences foster the competence and confidence necessary for personal transformation and the realization of "critical consciousness".

There was a predominance of retirees/pensioners 19 $(63 \%)$ and housewives $7(27 \%)$ in this study. According to Rosa et al. (2003), retirees and housewives are almost 8 times as likely to present morbidities. The mean chronic health conditions per patient individual corresponded to 3.5 \pm 1.5 . In this study, patients presented at least two chronic health conditions (mainly hypertension, diabetes mellitus and hypercholesterolemy); as a consequence they had to be treated by five different specialist physicians, to take multiple medications and to made difficult comprehension about drug therapy. Hypertension, diabetes, and asthma, major causes of morbidity and hospitalization, showed an important therapeutic drug gap (Naves, Silver, 2005). In the literature, it has been demonstrated that the number of drugs prescribed increases with the number of physicians seen (Lyra Jr. et al., 2004; Rollason, Vogt, 2003).

\section{Drug therapy profile}

During the study period were consumed 250 medicines, the mean $8.5 \pm 4$ drugs per elderly, the most of them $(81 \%)$ prescribed by physicians. Twenty outpatients received more than five different drugs prescribed. In Brazil, the true prevalence of the inappropriateness and redundancy among prescriptions is underestimated (Nóbrega et al., 2006; Gimenes et al., 2006; Lyra Jr. et al., 2004).

\section{Evaluation of Pharmaceutical Care intervention}

92 DTP were identified during the study, $3.0 \pm 1.5$ problems per patient. Twenty one patients showed a mean of 2.6 actual DTP and 0.5 potential DTP. $29 \%$ of them were detected by own patients, mainly a higher incidence of problems in the of the Safety category (64\%). These DTP had been caused by: diuretics (12 [19\%]), analgesics (10 [16\%]), calcium channel blockers $(9$ [14\%]) and angiotensin-converting-enzyme (ACE) inhibitors (8 [13\%]). The high medication consumption and high incidence of DTP (mainly in the of the Safety category) showed that the medication acted as harmful agent to the 
elderly health and caused symptoms such as: orthostatic hypotension, gastritis, dizziness and cramps.

In this study, 590 interventions were performed and documented, for both drug therapy (214) and health education (376). These interventions were equally distributed among the different chronic health conditions that the patients suffered.

Thirty five percent of 214 drug therapy interventions had been solved with the adjustment of medication regimens to elderly patients' daily routine. Other $65 \%$ required physician decision and the co-operative working between the research pharmacist, the prescribers and patients. This interaction was a key factor to solve and prevent the DTP in PHCU. Thus, the physicians agreed to change $86 \%$ of drug therapy regimen. By the end of the study, the interventions solved $69 \%$ of actual DTP and prevented $78.5 \%$ potential DTP. The results demonstrated an average of $4 \pm 2$ Pharmaceutical Care interviews to solve DTP.

All of the health education intervention that were made were accepted by the patients and implemented by them. Other studies showed the positive results of interventions, leading to the solution and prevention of DTP, reduction of treatment costs and satisfaction with Pharmaceutical Care program (Lee et al., 2006; Lyra Jr. et al., 2005; Vivian, 2002, Bernsten et al., 2001).

Some actual and potential DTP remained unresolved or were not prevented. The resolution and prevention of these DTP required modifications in drug regimens that depended exclusively on a medical decision.

\section{Reduction of weight response}

At the baseline, $15(50 \%)$ of the elderly presented overweight and $7(23 \%)$ obesity. The category of overweight and obesity was defined as a BMI of $25 \mathrm{~kg} / \mathrm{m}^{2}$ or greater. According to Ahrens et al. (2003), pharmacists can play a role in helping patients to manage their weight and decreasing the BP levels. After the interventions, the patients showed a reduction of $27 \%$ in weight (defined as weight loss greater than $7 \%$ ), but did not observe a significant difference in BMI results (Table I).

Others studies showed no statistically significant differences $(p<0,05)$ of BMI after pharmacist interventions (Castro et al., 2006; Garção, Cabrita, 2002). People, especially the elderly, have difficulty losing weight and maintaining weight loss (Ahrens et al., 2003). The elevated dropout rate suggests a need for other intervention strategies to motivate patients to reduce and maintain their weight loss.

Ahrens et al. (2003) suggested that to improve these results it is necessary to have a lengthier intervention
TABLE I - Body Mass Index (BMI) of elderly outpatients, at PHCU Dr. Ítalo Baruffi (Ribeirão Preto - SP), August 2003 to July 2004

\begin{tabular}{lcc}
\hline BMI & Baseline, $f(\%)$ & After, $\mathrm{f}(\%)$ \\
\hline Underweight (<18.5) & $0(0)$ & $0(0)$ \\
Normal weight (18.5 a 25) & $8(27)$ & $9(30)$ \\
Overweight (25 a 29.9) & $15(50)$ & $13(43.5)$ \\
Obese I (30 a 34.9) & $5(17)$ & $7(23.5)$ \\
Obese II (30 a 34.9) & $2(6)$ & $1(3)$ \\
\hline
\end{tabular}

period, training for the pharmacists and the interaction with other health professionals (e.g., physicians and dietitians). Thus, patients with obesity I and II that did not lose weight during this study were referred to physicians and dietitians at PHCU.

\section{Blood pressure response}

According to Blenkinsopp et al. (2000) the core of the intervention lies in its potential to empower patients to disclose their own concerns and questions about treatment. Empowerment terms implies the ability to take thoughtful action on one's own behalf (Freire, 1983). In this study, interventions such as in increasing the awareness of the importance of BP control were effective in reducing hypertension (Table II).

TABLE II - Changes in Blood Pressure (BP) of patients between baseline and after Pharmaceutical Care interventions, in PHCU Dr. Ítalo Baruffi (Ribeirão Preto SP), August 2003 to July 2004

\begin{tabular}{lccc}
\hline BP & $\begin{array}{c}\text { Baseline } \\
\text { Mean } \pm S D \\
(\mathrm{mmHg})\end{array}$ & $\begin{array}{c}\text { After } \\
\text { Mean } \pm S D \\
(\mathrm{mmHg})\end{array}$ & p Value \\
\hline Systolic & $146 \pm 19,5$ & $128 \pm 17$ & 0.0001 \\
Diastolic & $86.5 \pm 16$ & $74.5 \pm 13$ & 0.0001 \\
\hline
\end{tabular}

After empowerment, patients had significant mean reductions from the baseline in systolic $(18 \mathrm{mmHg})$ and diastolic $(12 \mathrm{mmHg})$ pressures $(\mathrm{p}<0.01)$. One metaanalysis of 30 clinical trials concluded that $5 \mathrm{mmHg}$ reduction in SBP lowered the risk of cardiovascular events and stroke by $25 \%$ to $30 \%$ (Staessen et al., 2003). Reduction in DBP of $5 \mathrm{mmHg}$ is associated with 34\% less strokes and 21\% less coronary heart disease (PiechowskiJózwiak, Bogousslavsky, 2006). 
At the beginning of the study, only 5 of the patients showed BP control $(\mathrm{BP}<120 / 80 \mathrm{mmHg})$, and after the Pharmaceutical Care intervention $13(43.5 \%)$ attained a BP below $120 / 80 \mathrm{~mm} \mathrm{Hg}$. At the end of the study, it was also observed that another $13(43.5 \%)$ of the patients achieved improvement $(\mathrm{e} \cdot 5 \mathrm{~mm} \mathrm{Hg}$ ) without the BP control, 2 $(6.5 \%)$ remained stable, and only $2(6.5 \%)$ worsened. Thus, there was an increase of $26.5 \%$ in the control of BP in the elderly group.

These findings are better than in other studies that reported the positive influence of pharmacists on outpatient BP control (Castro et al., 2006; Lee et al., 2006; Garção, Cabrita, 2002). This study is also consistent with three other studies that obtained the same reduction in BP values (Vivian, 2002; Mehos; Saseen; Mac Laughlin, 2000). Furthermore, it is important to highlight that $13(43.5 \%)$ of the hypertensive patients also had diabetes and JNC-VII (2003) guidelines recommend a pressure of $<130 / 85 \mathrm{~mm}$ $\mathrm{Hg}$ for these patients. Patients with diabetes and hypertension are four times more likely to have a cardiovascular event than patients without diabetes (George et al., 2001).

This study had several limitations as follows: researcher experience and education in Pharmaceutical Care, number of patients (convenience sample), and program conducted in only one setting. The Brazilian pharmacists' lack of experience in Pharmaceutical Care may have prevented the detection of more DTP that increase patient BP (Oliveira et al., 2005). Therefore, a longer training period for the researcher might have produced better results.

Because the population was small, it lacks statistical power to detect a more significant difference in baseline and follow-up BP in patients. Thus, to generalize the results, larger size samples would be needed.

Subjects were recruited from one PCHU, so extrapolating our results to other clinic settings and patient populations may be limited. Furthermore, recruitment and participation of patients was voluntary. Hence, it is possible that patients who did not participate were systematically different from those patients who participated.

\section{CONCLUSIONS}

The results demonstrate that although the Pharmaceutical Care program did not observe a significant difference in BMI results after 12 months, the BP control improved in $87 \%$ of the patients. Based on these findings, this study concludes that Pharmaceutical Care intervention can be an effective method in improving BP control in elderly outpatients, reducing the risk that hypertension represents for cardiovascular disease. Heightened awareness of the disease as well as increased pharmacistpatient and physician interaction may facilitate drug therapy modifications that are necessary to achieve desired BP goals.

After this study, the researcher gave training about practice of Pharmaceutical Care to 38 dispensing pharmacists from the Public Health-System of Ribeirão Preto. Nowadays, these pharmacists are perpetuating the practice introduced in the region.

Finally, this study provides framework for the future development of other outcomes studies in Brazilian ambulatory care patients.

\section{RESUMO}

\section{Efeito de intervenções de atenção farmacêutica na pressão arterial de pacientes idosos com hipertensão}

Oobjetivo deste estudo foi avaliar o efeito das intervenções farmacêuticas na prevenção e solução de problemas relacionados à farmacoterapia, ao índice de massa corporal e ao controle da pressão arterial de um grupo de pacientes idosos portadores de hipertensão arterial. O grupo de 30 pacientes assistidos na farmácia de uma unidade básica de saúde, em Ribeirão Preto (SP), Brasil, foi acompanhado por 12 meses. No estudo foi observado que as intervenções do programa de Atenção Farmacêutica otimizaram o uso dos medicamentos, reduziram os problemas de saúde causados pelos medicamentos e melhoraram as condições de saúde dos pacientes. As intervenções influenciaram tanto no cuidado prestado aos idosos como na obtenção de resultados de saúde positivos. Depois deste estudo, o pesquisador ministrou um curso de capacitação sobre a prática da Atenção Farmacêutica para 38 farmacêuticos da Secretaria Municipal de Saúde de Ribeirão Preto (SP). Atualmente, alguns destes farmacêuticos estão perpetuando a prática introduzida na região.

UNITERMOS: Hipertensão Arterial. Idosos. Atenção Farmacêutica.

\section{ACKNOWLEDGEMENTS}

Thanks are due to all patients who participated in this study. The authors acknowledge Profa. Dra. Claudia Santos da Escola de Enfermagem de Ribeirão Preto/ USP for her valuable comments. This study was supported by CAPES and FAPESP. 


\section{REFERENCES}

AHRENS, R. A.; HOWER, M.; BEST, A.M. Effects of weight reduction interventions by community pharmacists. J. Am. Pharm. Assoc., v. 43, n. 5, p. 583590, 2003.

BERNSTEN, C.; BJÖRKMAN, I.; CARAMONA, M.; CREALEY, G.; FRØKJÆR, B.; GRUNDBERGER, E. Improving the well-being of elderly patients via community pharmacy-based provision of pharmaceutical care. Drugs Aging., v.18, n.1, p.63-77, 2001.

BLENKINSOPP,A.; PHELAN, J.B.; DAKHIL, N. Extended adherence support by community pharmacists for patients with hypertension: a randomized controlled trial. Int. $J$. Pharm. Pract., v.24, n.2, p.189-200, 2000.

CASTRO. M.S.; FUCHS, F.; SANTOS, M.C.; MAXIMILIANO, P.; GUS, M.; MOREIRA, L.B.; FERREIRA, M.C. Pharmaceutical care program for patients with uncontrolled hypertension: report of a doubleblind clinical trial with ambulatory blood pressure monitoring. Am. J. Hypertens. , v. 19, n.5, p.528-533, 2006.

CHOBANIAN, A.V. Control of hypertension - an important national priority [editorial]. N. Engl. J. Med. , v.345, n.7, p.534-535, 2001.

CIPOLLE, R.J.; STRAND, L.M.; MORLEY, P.C. Pharmaceutical care practice: the clinician's guide. 2. ed. New York: Mc Graw Hill, 2004. 394p.

COMITÉ DEL CONSENSO. Segundo Consenso de Granada sobre Problemas Relacionados con Medicamentos. Ars. Pharm., v.43, n.3-4, p.175-184, 2002.

CURRIE, J.D.; DOUCETTE, W.R.; KUHLE, J.; SOBOTKA, J.; MILLER, W. A.; MCDONOUGH, R.P. et al. Identification of essential elements in the documentation of pharmacist-provided care. J. Am. Pharm. Assoc., v.43, n.1, p.41-49, 2003.

ERWIN, W.G. The role of consultant pharmacist. Consult. Pharm., v.14, n.12, p.1342-1351, 1999.

FREIRE P. Education for critical consciousness. New York: Continuum International Publishing Group, 2005. 146p.
GARÇÃO, J.A.; CABRITA, J. Evaluation of a pharmaceutical care program for hypertensive patients in rural Portugal. J. Am. Pharm. Assoc., v.42, n.6, p.858864, 2002.

GEORGE, P. B.; TOBIN, K. J.; CORPUS, R. A.; DEVLIN, W. ; O'NEILL, W. W. Treatment of cardiac risk factors in diabetic patients: how well do we follow the guidelines? Am. Heart J., v.142, n.5, p.857-863, 2001.

GIMENES, F. R. E.; MIASSO, A.I.; LYRA Jr., D.P.; GROU; C. R. Electronic prescription as contributory factor for hospitalized patients' safety. Pharm. Pract., v.4, n.1, p.1317, 2006.

GODLEY, P., NGUYEN,A.; YOKOHAMA, K.; ROHACK, J.; WOODWARD, B.; CHIANG, T. Improving hypertension care in a large group-model MCO. Am. J. Health Syst. Pharm., v.60, n.14, p.1, 2003.

PIECHOWSKI-JÓZWIAK, B.; BOGOUSSLAVSKY, J. Pharmacotherapy of Stroke. Eur. Neurol. Dis. , n. 3, p. 5258, 2006.

HEPLER, C.D. STRAND, L.M. Oportunities and responsabilities in pharmaceutical care. Am. J. Hosp. Pharm., v. 47, p. 533-543, 1990.

KOECHELER, J.; ABRAMOWITZ, P.W.; SWIM, S.E.; DANIELS, C.E. Indicators for the selection of ambulatory patients who warrant pharmacist monitoring. Am. J. Hosp. Pharm., v.46, n.4, p.728-732, 1989.

KOHN, L.T.; CORRIGAN, J.M.; DONALDSON, M.S., (Eds.). To err is human: building a safer health system. Washington, National Academy Press, 2000.320p.

LEE, J.K.; GRACE, K.A.; TAYLOR, A.J. Effect of a pharmacy care program on medication adherence and persistence, blood pressure, and low-density lipoprotein cholesterol: a randomized controlled trial. JAMA, v.296, n.21, p.2563-2571, 2006.

LYRA JUNIOR, D.P.; ROCHA, C.E.; ABRIATA, J.P.; GIMENES, F.R.E. GONZALES, M.M.; PELÁ, I.R. Influence of pharmaceutical care intervention and communication skills on the improvement of pharmacotherapic outcomes with elderly brazilian outpatients. Pat. Educ. Couns., v.68, n.2, p.186-192, 2007. 
LYRA Jr. , D.P.; AMARAL, R.T.; VEIGA, E.V.; CARNIO, E.C.; NOGUEIRA, M.S.; PELÁ, I.R.A farmacoterapia no idoso: revisão sobre a abordagem multiprofissional no controle da hipertensão arterial sistêmica. Rev. Latino-Am. Enfermagem, v.14, n.3, p.435-441, 2006.

LYRA Jr., D.P.; AMARAL, R.T.; ABRIATA, J.P.; PELÁ, I.R. Satisfacción como resultado de un programa de atención farmacéutica para pacientes ancianos en Ribeirão PretoSão Paulo (Brasil). Seguim. Farmacoter., v.3, n.1, p.3042, 2005.

LYRA Jr., D.P.; PRADO, M.C.T.A.; ABRIATA, J.P.; PELÁ, I.R. Prescription orders as cause of risk of drug-related problems. Seguim. Farmacoter., v.2, n.2, p.86-96, 2004.

MEHOS, B.M.; SASEEN, J.J.; MAC LAUGHLIN, E.J. Effect of pharmacist intervention and initiation of home blood pressure monitoring in patients with uncontrolled hypertension. Pharmacotherapy, n.20, v.11, p.13841389, 2000.

MUXFELDT, E.S.; NOGUEIRA, A.R.; SALLES, G.F.; BLOCH, K.V. Demographic and clinical characteristics of hypertensive patients in the internal medicine outpatient clinic of a university hospital in Rio de Janeiro. São Paulo Med. J., v.122, n.3, p.87-93, 2004.

NAVES, J.O.S.; SILVER, L.D. Evaluation of pharmaceutical assistance in public primary care in Brasília, Brazil. Rev. Saúde Pública, v.39, n.2, p.233-230, 2005.

NÓBREGA, O.T.; MELO, G.F.; KARNIKOWSKI, M.G.O. Pattern of drugs prescribed for community-residing middle-aged and older adults from the outskirts of Brasília. Rev. Bras. Ciênc. Farm., v.41, n.2, p.271-277, 2005.

OLIVEIRA, A.B; OYAKAWA, C.N. ; MIGUEL, M.D.; ZANIN, S.M.W.; MONTRUCCHIO, M.D. Obstáculos da atenção farmacêutica no Brasil. Rev. Bras. Ciênc. Farm., v.41, n.4, p.409-413, 2005.

ROLLASON, V. ; VOGT, N. Reduction of polypharmacy in the elderly: a systematic review of the role of the pharmacist. Drugs Aging, v.20, n.11, p.817-832, 2003.
ROSA, T.E.C.; BENÍCIO, M.H.D.; LATORRE, M.R.D.O.; RAMOS, L.R. Determinant factors of functional status among the elderly. Rev. Saúde Pública, v.37, n.1, p.40-44, 2003.

ROTER, D.L.; MARGALIT-STASHEFSKY, R.; RUDD, R. Current perspectives on patient education in the U. S. Pat. Educ. Couns., v.44, p.79-86, 2001.

STAESSEN, J.A.; WANG, J.G.; THIJS, L. Cardiovascular prevention and blood pressure reduction: a quantitative overview updated until 1 March 2003. J. Hypertens., v.21, n.6, p.1055-1076, 2003.

VIVIAN, E.M. Improving pressure control in a pharmacistmanaged hypertension clinic. Pharmacotherapy, v.22, n.12, p.1533-1540, 2002.

ZAITUNE, M.P.A.; BARROS, M.B.A.; CÉSAR, C.L.G.; CARANDINA, L.; GOLDBAUM, M. Hipertensão arterial em idosos: prevalência, fatores associados e práticas de controle no Município de Campinas, São Paulo, Brasil. Cad. Saúde Pública, v.22, n.2, p.285-294, 2006.

SOUZA, W.A.; YUGAR-TOLEDO, J.C.; MENDES, G.B.; SABHA, M.; MORENO Jr., H. Effect of pharmaceutical care on blood pressure control and health-related quality of life in patients with resistant hypertension. Am. $J$. Health Syst. Pharm., v.64, n.18, p.1955-1961, 2007.

ZILLICH, A.J.; SUTHERLAND, J.M.; KUMBERA, P.A.; CARTER, B.L. Hypertension outcomes through blood pressure monitoring and evaluation by pharmacists (HOME Study). J. G. Intern. Med., v.20, n.12, p.10911096, 2005.

WORLD HEALTH ORGANIZATION (WHO), International Society of Hypertension writing group. 2003 World Health Organization /International Society of Hypertension (ISH) statement on management of hypertension. J. Hypertens., v.21, n.11, p.1983-1992, 2003.

Recebido para publicação em 11 de janeiro de 2007 Aceito para publicação em 01 de abril de 2008 